\title{
Recycling of waste oils with different composition using flexible type technology
}

\author{
C Irina A. Permyakova, ${ }^{+}$Vladimir V. Volkhin, ${ }^{*}$ and Galina V. Leontieva \\ Department of Chemistry and Biotechnology. Perm National Research Polytechnic University. \\ Komsomolsky Ave., 29. Perm, 614990. Russia. Phone: +7 (3422) 39-15-11. \\ E-mail:permyakova-i88@yandex.ru
}

*Supervising author; ${ }^{+}$Corresponding author

Keywords: waste oils, flexible type technology, triglycerides, fatty acids, low-molecular alcohols, esterification, transesterification.

\begin{abstract}
Present issue proposes a solution to the problem of the waste oils with different composition recycling into esters of fatty acids and low-molecular alcohols by using flexible type technology. Waste oils differ in the composition of hydrocarbon radicals of the vegetable oils triglycerides and in the content of the free fatty acids impurities. For waste oils processing it is advisable to use technology options that differ in combinations of basic technological operations. An algorithm is proposed for selecting the main technological operations and their combinations for inclusion in the technology process, taking into account the composition of the recycling raw materials and the type of product obtained. The flexibility of the technology is provided by using different combinations of reactor blocks, each of which is designed to perform one of the provided technological operations. The developed flexible type technology was tested in the recycling of experimental batch of the low-eruption rapeseed oil waste.
\end{abstract}

\section{References}

[1] M. Balat. Prospects for worldwide biodiesel market development. Energy Sources. 2009. Vol.4. P.48-58.

[2] S. Madiwale, V. Bhojwani. An overview on production, properties, performance and emission analysis of blends of biodiesel. Procedia technology. 2016. Vol.25. P.963-973.

[3] N.A. Zainal, N.W.M. Zulkifli, M. Gulzar, H.H. Masjuki. A review on the chemistry, production and technological potential of bio-based lubricants. Renewable and sustainable energy reviews. 2018. Vol.82. P.80-102.

[4] D.Y.C. Leung, X. Wu, M.K.H. Leung. A review on biodiesel production using catalyzed transesterification. Applied energy. 2010. Vol.2010. No.4. P.1083-1095.

[5] J.M. Marchetti. Heterogeneous esterification of oil with high amount of free fatty acids. Fuel. 2007. Vol.86. P.906-910.

[6] M.G. Kulkarni. Waste cooking oil - an economical source for biodiesel: a review. Ind. Eng. Chem. Res. 2006. Vol.45. P.2901-2913.

[7] M. Canakci. Biodiesel production from oils and fats with high free fatty acids. Trans ASAE. 2001. Vol.44. No.6. P.1429-1436.

[8] M.K. Lam. Homogeneous, heterogeneous and enzymatic catalysis for transesterification of high free fatty acid oil (waste cooking oil) to biodiesel: a review. Biores. technol. advances. 2010. Vol.28. P.500-518.

[9] RF Patent 2625676 S1 (Publ. 2017). The method of fatty acids extraction from oils.

[10] I.A. Permyakova, V.V. Vol'khin, O.S. Medvedeva. Extraction in Emulsion Mode of Higher Fatty Acids from Vegetable Oils by Methanol or Ethanol in Esters Production. Russian Journal of Applied Chemistry. 2020. Vol.93. No.3. P.437-448. (russian)

[11] Technology of oil processing. Ed. by S. Harutyunyan and others. Moscow: Pishchepromizdat. 1988. P.4546. (russian)

[12] L.H. Miftakhova. Modeling of rapeseed oil and ethanol transesterification reaction in supercritical fluid conditions in a continuous flow reactor. Bulletin of the technological University. 2015. Vol.18. No.12. P.19-22. (russian)

[13] R.A. Usmanov. Biodiesel fuel. Transesterification in supercritical fluid conditions: monograph. Kazan: Butlerov heritage. 2017. 360p. (russian) 
RECYCLING OF WASTE OILS WITH DIFFERENT COMPOSITION USING FLEXIBLE TYPE TECHNOLOGY 66-78

[14] I.A. Permyakova, V.V. Vol'khin, D.A. Kazakov, N.S. Voronina. Algorithm for calculating phase equilibria in systems including higher fatty acids, triacylglycerols and low-molecular alcohols. Theoretical foundations of chemical technology. 2018. Vol.52. No.6. P.676-688. (russian)

[15] I.A. Permyakova, E.A. Kasatkina, G.V. Leontieva, and V.V. Volkhin. The influence of acidity on the phase equilibrium of the systems, including triglycerides, fatty acid and low molecular alcohol.

Butlerov Communications. 2017. Vol.52. No.10. P.74-87. DOI: 10.37952/ROI-jbc-02/17-52-10-74

[16] G. Guan, N. Sakurai, K. Kusakabe. Synthesis of biodiesel from sunflower oil at room temperature in the presence of various cosolvents. Chem. Eng. J. 2009. Vol.146. P.302-306.

[17] K.F. Kara, F. Ouanji, Lotfi El M., Mahi M. El, M. Kacimi, M. Ziyad. Biodiesel production from waste fish oil with high free fatty acid content from Moroccan fish-processing industries. Egypt. J. Petrol. 2017. Vol.27. No.2. P.249-255.

[18] I.A. Permyakova, E.A. Kasatkina, G.V. Leontieva, and V.V. Volkhin. Conversion of fat-containing wastes by acid-catalyzed esterification reaction in systems with controlled phase condition. Butlerov Communications. 2018. Vol.54. No.4. P.56-74. DOI: 10.37952/ROI-jbc-02/18-54-4-56 